\title{
Serum progranulin levels are elevated in infertile women with obesity
}

\author{
Podwyższone stężenia progranuliny w surowicy bezpłodnych kobiet z otyłością
}

Umit Gorkem ${ }^{1}$, Zeynep Ozturk Inal ${ }^{2}$, Hasan Ali Inal ${ }^{2}$, Mehmet Omar Bostanci'

${ }^{1}$ Medical Faculty, Hitit University, Çorum, Turkey

${ }^{2}$ Konya Education and Research Hospital, Konya, Turkey

\begin{abstract}
Introduction: The aim of the present study was to investigate the changes in serum progranulin and sex hormone levels in infertile women with obesity.

Material and methods: A total of 171 infertile women who had fertility desire were included in this cross-sectional study. The initial assessment included measurements of weight, height, waist circumference, and hip circumference to calculate body mass index (BMI) and waist/hip ratio. All participants were categorised into two groups in accordance with BMI as a control group $\left(<30 \mathrm{~kg} / \mathrm{m}^{2}, \mathrm{n}=135\right)$ and a study group $\left(\geq 30 \mathrm{~kg} / \mathrm{m}^{2}, \mathrm{n}=36\right.$ ). After anthropometric measurements, venous blood samples were taken for analyses of oestradiol and follicle stimulating hormone (FSH), luteinising hormone, total testosterone (TT), 17-hydroxyprogesterone, dehydroepiandrosterone sulphate, anti-Müllerian hormone, and progranulin.

Results: The present study demonstrated that the overweight women had higher FSH levels $(\mathrm{p}<0.01)$. Elevated TT levels were detected in obese women $(p<0.05)$. Progranulin concentrations were higher in the study group than in the control group $(p<0.05)$. Regression analysis demonstrated that there was a relationship between the serum progranulin concentrations and BMI $(p<0.05)$.

Conclusions: Our findings support that the elevated progranulin levels are associated with obesity in infertile women. Therefore, infertile and obese patients may benefit if their serum progranulin levels decrease. Further studies are needed to elucidate this issue. (Endokrynol Pol 2018; 69 (6): 661-666)
\end{abstract}

Keywords: progranulin; granulin; obesity; infertility

\section{Streszczenie}

Wstęp: Celem badania była analiza zmian stężeń progranuliny i hormonów płciowych u bezpłodnych kobiet z otyłością.

Materiał i metody: Do przekrojowego badania włączono 171 bezpłodnych kobiet, które chciały zajść w ciążę. Ocena wstępna obejmowała pomiary masy ciała, wzrostu, obwodu talii i bioder w celu obliczenia wskaźnika masy ciała (BMI) i współczynnika talia/biodra. Wszystkie uczestniczki podzielono na dwie grupy w zależności od wartości BMI, tworząc grupę kontrolną $\left(<30 \mathrm{~kg} / \mathrm{m}^{2}, \mathrm{n}=135\right)$ oraz grupę badaną $\left(\geq 30 \mathrm{~kg} / \mathrm{m}^{2}, \mathrm{n}=36\right.$ ). Po wykonaniu pomiarów antropometrycznych od wszystkich kobiet pobrano próbki krwi żylnej do oznaczeń stężeń estradiolu i hormonu folikulotropowego (FSH), hormonu luteinizującego, testosteronu całkowitego (TT), 17-hydroksyprogesteronu, siarczanu dehydroepiandrosteronu, hormonu antymüllerowskiego i progranuliny.

Wyniki: W badaniu wykazano, że u otyłych kobiet stężenie FSH jest podwyższone $(\mathrm{p}<0,01)$. W tej grupie kobiet stwierdzono również podwyższone stężenie TT $(\mathrm{p}<0,05)$. Stężenie progranuliny było wyższe w grupie badanej niż w grupie kontrolnej $(\mathrm{p}<0,05)$. W analizie regresji wykazano zależność między stężeniem progranuliny w surowicy a BMI $(\mathrm{p}<0,05)$.

Wnioski: Uzyskane wyniki potwierdzają, że u bezpłodnych kobiet podwyższone stężenie progranuliny wiąże się z otyłością. Dlatego obniżenie stężenia progranuliny w surowicy może przynieść korzystne efekty u kobiet z bezpłodnością i otyłością. Potrzebne są dalsze badania w tej dziedzinie. (Endokrynol Pol 2018; 69 (6): 661-666)

Słowa kluczowe: progranulina; granulina; otyłość; bezpłodność

\section{Introduction}

Progranulin is also known as proepithelin, or plasma cell derived growth factor and a precursor of granulin for proteolytic cleavage process. It was originally discovered as an acrosomal glycoprotein, and named as acrogranin, which was found to be synthesised during spermatogenesis of guinea pigs [1]. It has some growth factor-like properties, and it is involved in early embryogenesis [2], wound repair, and tissue remodel- ling [3]. It has the properties of a pluripotent growth factor mediating wound healing, tumorigenesis, and progression of cell cycle [4]. It has also been suggested that it plays a role in various disorders including breast, ovarian, cervical, gastrointestinal, and kidney cancers [5-9] as well as neurodegenerative disorders including frontotemporal dementia [10] and rheumatoid arthritis [11]. Progranulin is protein produced in response to hypoxia or acidosis [12]. It has complex physiological and pathological functions because it has both anti- 
and pro-inflammatory characteristics $[13,14]$. The data suggest that the full-length form of progranulin exerts trophic and anti-inflammatory actions. However, proteolytic cleavage of progranulin produces granulin peptides that induce inflammatory action [15].

Recently, obesity has been increasing worldwide as an epidemic. It has been associated with a chronic low-grade inflammatory state, which is characterised by increased pro-inflammatory and decreased anti-inflammatory factors. More than one third of the adult population is obese in Turkey, similarly to most of the world [16, 17]. The World Health Organisation has defined obesity as body mass index (BMI) equal to or greater than $30 \mathrm{~kg} / \mathrm{m}^{2}$ [18].

Obese women are more susceptible to anovulation and abnormal uterine bleeding, infertility, miscarriage, as well as antenatal and neonatal complications in which the mechanism is complex and multifactorial [19]. Obese women also show impaired development of ovarian follicles and oocytes, and abnormal fertilisation, embryo development, and implantation [20, 21].

Therefore, progranulin found in adipose tissue may participate in chronic inflammation associated with obesity. To our knowledge, only scarce studies in the literature have investigated the role of progranulin on the pathogenesis of obesity and infertility. Thus, we aimed to investigate whether there were serum progranulin changes and any correlations between progranulin and sex hormones in obese infertile women.

\section{Material and methods}

\section{Study population and design}

All of the 171 women admitted to the Reproductive Endocrinology Department of Hitit University Hospital for fertility desire in Corum, Turkey between January 1 and September 302016 were included in this cross-sectional study. The study protocol was approved by the Institutional Review Board of Ankara Numune Education and Research Hospital (reference number: E-15-563), in accordance with the Declaration of Helsinki, 2013 Brazil version. Written, informed consent was obtained from each participant before starting the study. The exclusion criteria were accepted as history of pelvic surgery, chemotherapy and/or radiotherapy, ovarian masses, polycystic ovarian syndrome, endometriosis, severe systemic diseases including diabetes mellitus, cardiovascular, renal, hepatic, autoimmune or endocrine disorders, use of drugs likely to affect ovarian functions, smoking or alcohol consumption, and pregnancy or lactation. Infertility was described as the failure to conceive in one year with regular sexual activity. The participant women who had a diagnosis of unexplained infertility were included in the present study.
The initial assessments of the patients included the measurements of weight, height, waist circumference (WC), and hip circumference (HC) to calculate BMI and waist/hip ratio (WHR). BMI was calculated as weight $(\mathrm{kg}) /$ height $^{2}\left(\mathrm{~m}^{2}\right)$. All participants were categorised into two groups in accordance with their BMI, as a control group $\left(<30 \mathrm{~kg} / \mathrm{m}^{2}, \mathrm{n}=135\right)$ and a study group $\left(\geq 30 \mathrm{~kg} / \mathrm{m}^{2}, \mathrm{n}=36\right.$ ). WC was measured at the mid-point of the lowest margin of $12^{\text {th }}$ rib and the lateral iliac crest during normal expiration. HC was measured at the maximum extension of the major trochanters. All anthropometric measurements were performed with the same scale, and by the same observer.

\section{Data collection and assays}

Venous blood samples of the participants were obtained from their antecubital veins between 08:00 and 10:00 after an eight-hour fasting period on menstrual days 2-5 for oestradiol $\left(\mathrm{E}_{2}\right)$, follicle stimulating hormone (FSH), luteinising hormone ( $\mathrm{LH})$, total testosterone (TT), 17-Hydroxyprogesterone (17OHP), dehydroepiandrosterone sulphate (DHEAS), anti-Müllerian hormone $(\mathrm{AMH})$, and progranulin measurements. The samples were allowed to clot completely at room temperature, and then they were centrifuged within $30 \mathrm{~min}$ at $3000 \mathrm{rpm}$ for 20 minutes. The serums for $\mathrm{AMH}$ and progranulin measurements were frozen at $-80^{\circ} \mathrm{C}$ within two hours, until they were analysed. The serums were analysed on a daily basis for $\mathrm{E}_{2}, \mathrm{FSH}, \mathrm{LH}, \mathrm{TT}, 17 \mathrm{OHP}$, and DHEAS using electrochemiluminescence immunoassay (ECLIA) method and an auto-analyser (Cobas 6000, E 601 Roche Diagnostics, GmbH, Mannheim, Germany). The AMH samples were measured with the ECLIA method using an auto-analyser (Cobas 6000, 601 Roche Diagnostics, GmbH, Mannheim, Germany).

The serum progranulin levels were determined using commercially available enzyme-linked immunosorbent assay (ELISA) kit developed for PGRN (Biotek Synergy HT, Cloud-Clone Corp., Houston, USA) and given as $\mathrm{ng} / \mathrm{mL}$. CVs for intra-assay were $<10 \%$, CVs for inter assay were $<12 \%$, sensitivity was $0.05 \mathrm{ng} / \mathrm{mL}$, and assay range was $1.56-100 \mathrm{ng} / \mathrm{mL}$.

\section{Statistical analysis}

All data analyses were performed using SPSS (Statistical Packages for The Social Sciences) software, version 21 (SPSS Inc., Chicago, USA). The Kolmogorov-Smirnov and Shapiro-Wilk tests were used to test normality of distribution. Continuous parameters were presented as mean \pm standard deviation (SD). Continuous variables were compared using independent samples t-test due to normally distributed data. Pearson or Spearman correlation analysis, where appropriate, was used to test whether progranulin showed any significant linear 
relationship with other study parameters. Multiple linear regression analysis was used to investigate the associations between progranulin and the other study parameters. A p value less than 0.05 was considered as statistically significant.

\section{Results}

The comparisons of anthropometric and biochemical parameters among the overweight and obese women in relation with BMI are demonstrated in Table I. No significant difference in mean age was observed between the control and study groups ( $\mathrm{p}>0.05)$. As expected, the anthropometric measurements including BMI, WC, and $\mathrm{HC}$ were higher in the study group $(\mathrm{p}<0.001)$. However, the mean WHR did not differ between the two groups ( $p$ > 0.05). Serum $E_{2}, L H, 17 \mathrm{OHP}$, and DHEAS levels were similar in the control and study groups $(p>0.05)$. The non-obese women had higher FSH levels compared to obese women $(\mathrm{p}<0.01)$. Elevated TT levels were detected in obese women $(\mathrm{p}<0.05)$. Moreover, the comparisons of circulating AMH levels did not confirm any difference between the two groups $(p>0.05)$. The comparisons revealed increased progranulin concentrations in the study group ( $p<0.05)$.

Correlation analysis showed that the BMI $(r=0.228$, $\mathrm{p}=0.003)$, WC $(\mathrm{r}=0.171, \mathrm{p}=0.018)$, and HC $(\mathrm{r}=0.172$, $\mathrm{p}=0.025)$ correlated with the levels of progranulin (Table II).

Multiple linear regression analysis revealed that there was a relationship between the serum progranulin concentrations and BMI. In another words, it was observed that the BMI could be a variable affecting progranulin levels, and the other variables could have no effect on progranulin levels, as shown in Table III $(\mathrm{p}<0.05)$.

\section{Discussion}

In this study, we investigated the relationship between serum progranulin levels and obesity in infertile women and found that serum progranulin levels were significantly higher in obese infertile women when compared to overweight infertile women. Only scarce clinical studies demonstrated positive correlations between circulating progranulin levels and components of metabolic syndrome, including insulin resistance (IR), dyslipidaemia, and obesity. High progranulin levels have been reported in obesity [22]. Both animal [23] and human studies [24, 25] have reported a relationship between progranulin levels and adiposity.

It was also demonstrated that serum progranulin was associated with parameters of adiposity, IR, and
Table I. Anthropometric and biochemical characteristics among the overweight and obese women according to $B M I$

Tabela I. Parametry antropometryczne i biochemiczne kobiet z otyłościq i nadwaga w zależności od wartości wskaźnika $B M I$

\begin{tabular}{lccc}
\hline Parameters & $\begin{array}{c}\text { Control group } \\
(\mathbf{n}=\mathbf{1 3 5})\end{array}$ & $\begin{array}{c}\text { Study group } \\
(\mathbf{n}=\mathbf{3 6})\end{array}$ & $\mathbf{p}$ \\
\hline Age $($ year) & $30.2 \pm 5.9$ & $30.4 \pm 6.2$ & 0.812 \\
\hline BMI $\left[\mathrm{kg} / \mathrm{m}^{2}\right]$ & $24.2 \pm 3.0$ & $33.7 \pm 3.3$ & $<0.001^{*}$ \\
\hline WC $[\mathrm{cm}]$ & $86.8 \pm 11.0$ & $101.4 \pm 12.9$ & $<0.001^{*}$ \\
\hline HC $[\mathrm{cm}]$ & $102.0 \pm 8.2$ & $116.8 \pm 7.6$ & $<0.001^{*}$ \\
\hline WHR & $0.9 \pm 0.1$ & $0.9 \pm 0.1$ & 0.190 \\
\hline $\mathrm{E}_{2}[\mathrm{pg} / \mathrm{mL}]$ & $45.4 \pm 24.2$ & $43.8 \pm 41.8$ & 0.676 \\
\hline FSH [IU/L] & $7.4 \pm 2.4$ & $6.3 \pm 1.5$ & $0.006^{*}$ \\
\hline LH [IU/L] & $6.7 \pm 2.8$ & $6.1 \pm 3.3$ & 0.237 \\
\hline TT $[\mathrm{ng} / \mathrm{dL}]$ & $24.1 \pm 13.5$ & $33.4 \pm 41.1$ & $0.027^{*}$ \\
\hline $170 \mathrm{HP}[\mathrm{ng} / \mathrm{dL}]$ & $141.0 \pm 46.0$ & $76.0 \pm 45.1$ & 0.399 \\
\hline DHEAS [mcg/dL] & $221.7 \pm 100.0$ & $213.4 \pm 92.4$ & 0.656 \\
\hline AMH $[\mathrm{ng} / \mathrm{dL}]$ & $4.2 \pm 3.8$ & $4.3 \pm 4.1$ & 0.936 \\
\hline Progranulin $[\mathrm{ng} / \mathrm{mL}]$ & $2.7 \pm 1.1$ & $3.2 \pm 1.1$ & $0.019^{*}$ \\
\hline
\end{tabular}

*statistically significant

$\mathrm{BMI}$ - body mass index; WC — waist circumference; $\mathrm{HC}$ - hip circumference; WHR - waist-hip ratio; $\mathrm{E}_{2}$ - oestradiol; FSH — follicle stimulating hormone; $\mathrm{LH}$ - luteinizing hormone; $\mathrm{TT}$ - total testosterone; 170HP - 17-hydroxyprogesterone; DHEAS - dehydroepiandrosterone sulphate; $\mathrm{AMH}$ - anti-Müllerian hormone

Table II. Correlations between serum progranulin and other parameters

Tabela II. Korelacje między stężeniem progranuliny $w$ surowicy a innymi parametrami

\begin{tabular}{lcc}
\hline & $\mathbf{r}$ & $\mathbf{p}$ \\
\hline Age $($ year) & 0.074 & 0.335 \\
\hline BMI $\left[\mathrm{kg} / \mathrm{m}^{2}\right]$ & 0.228 & $0.003^{*}$ \\
\hline WC $[\mathrm{cm}]$ & 0.171 & $0.018^{*}$ \\
\hline HC $[\mathrm{cm}]$ & 0.172 & $0.025^{*}$ \\
\hline WHR & 0.130 & 0.089 \\
\hline $\mathrm{E}_{2}[\mathrm{pg} / \mathrm{mL}]$ & 0.045 & 0.558 \\
\hline FSH $[\mathrm{IU} / \mathrm{L}]$ & 0.081 & 0.292 \\
\hline LH $[\mathrm{IU} / \mathrm{L}]$ & -0.079 & 0.303 \\
\hline TT $[\mathrm{ng} / \mathrm{dL}]$ & 0.031 & 0.689 \\
\hline $170 \mathrm{HP}[\mathrm{ng} / \mathrm{dL}]$ & 0.017 & 0.822 \\
\hline DHEAS $[\mathrm{mcg} / \mathrm{dL}]$ & -0.052 & 0.497 \\
\hline AMH $[\mathrm{ng} / \mathrm{dL}]$ & -0.094 & 0.219 \\
\hline
\end{tabular}

*statistically significant

$\mathrm{BMI}$ - body mass index; WC — waist circumference; $\mathrm{HC}$ - hip circumference; WHR - waist-hip ratio; $\mathrm{E}_{2}$ - oestradiol; FSH — follicle stimulating hormone; $\mathrm{LH}$ - luteinizing hormone; TT — total testosterone; 170HP - 17-hydroxyprogesterone; DHEAS — dehydroepiandrosterone sulphate; $\mathrm{AMH}$ - anti-Müllerian hormone 
Table III. Outcomes of multiple linear regression analysis - progranulin level increases proportionally with BMI Tabela III. Wyniki analizy liniowej regresji wielokrotnej—stężenie progranuliny podwyższa się proporcjonalnie do wartości BMI

\begin{tabular}{|c|c|c|c|c|c|}
\hline \multirow[t]{2}{*}{ Parameters } & \multirow[t]{2}{*}{ Coefficient } & \multirow[t]{2}{*}{ Standard Error } & \multicolumn{2}{|c|}{ 95\% Confidence Interval } & \multirow[t]{2}{*}{$\mathbf{p}$} \\
\hline & & & Lower Bound & Upper Bound & \\
\hline (Constant) & 0.123 & 1.288 & -2.415 & 2.661 & 0.924 \\
\hline Age [year] & -0.004 & 0.016 & -0.036 & 0.029 & 0.829 \\
\hline BMI [kg/m²] & 0.050 & 0.030 & 0.011 & 0.088 & $0.011^{*}$ \\
\hline WC [cm] & -0.114 & 0.095 & -0.301 & 0.072 & 0.231 \\
\hline $\mathrm{HC}[\mathrm{cm}]$ & 0.091 & 0.081 & -0.066 & 0.250 & 0.258 \\
\hline WHR & 1.149 & 1.223 & -1.301 & 3.493 & 0.349 \\
\hline $\mathrm{E}_{2}[\mathrm{pg} / \mathrm{mL}]$ & 0.002 & 0.003 & -0.004 & 0.008 & 0.507 \\
\hline FSH [IU/L] & 0.071 & 0.043 & -0.04 & 0.156 & 0.100 \\
\hline $\mathrm{LH}[\mathrm{IU} / \mathrm{L}]$ & -0.009 & 0.035 & -0.077 & 0.059 & 0.799 \\
\hline $\mathrm{TT}[\mathrm{ng} / \mathrm{dL}]$ & 0.001 & 0.004 & -0.007 & 0.010 & 0.723 \\
\hline $170 \mathrm{HP}[\mathrm{ng} / \mathrm{dL}]$ & 0.007 & 0.021 & -0.035 & 0.049 & 0.745 \\
\hline DHEAS [mcg/dL] & -0001 & 0.001 & -0.003 & 0.001 & 0.585 \\
\hline AMH [ng/dL] & 0.002 & 0.027 & -0.052 & 0.055 & 0.945 \\
\hline
\end{tabular}

${ }^{*}$ statistically significant

$\mathrm{BMI}$ — body mass index; WC — waist circumference; $\mathrm{HC}$ - hip circumference; WHR — waist-hip ratio; $\mathrm{E}_{2}$ - oestradiol; FSH — follicle stimulating hormone; LH — luteinizing hormone; TT — total testosterone; 170HP — 17-hydroxyprogesterone; DHEAS — dehydroepiandrosterone sulphate; AMH — anti-Müllerian hormone

several inflammatory factors [24]. Progranulin is particularly more highly expressed in visceral adipose tissues of morbid-obese, insulin-resistant patients [22, 26]. In a research from Brazil, the authors demonstrated that progranulin may be involved in the pathogenesis of obesity and become a target for metabolic disorder prevention or treatment [27]. When taken altogether, this evidence supports that progranulin plays a regulatory role in glucose and energy homeostasis, and it is possible that it may contribute to the progression of metabolic syndrome [28].

Qu et al. reported higher interleukin 6 (IL-6) levels in obese patients, and high IL-6 levels were associated with increased circulating progranulin levels [24]. Positive correlations of progranulin with C-reactive protein and IL-6 were also reported in human studies [22, 24]. In another study, progranulin seemed to play a role on this process, by recruiting monocytes into adipose tissue as well as monocyte chemoattractant protein-1, due to its characteristic activity [29].

It was suggested that progranulin could be involved in the growth of adipose tissue [30]. It has been known that angiogenesis follows expansion of fat mass in obesity [31]. In fact, progranulin has previously been linked to formation of vessels [32]. However, the role of progranulin in adipogenesis is not yet clear. Moreover, progranulin shows an anorexigenic effect in the lean state, but a resistance is observed, and this leads to increased food intake [33]. Although progranulin shows an anti-inflammatory effect in acute conditions of ischaemia-perfusion injury $[34,35]$, it is associated with IR and inflammation in obesity, as a chronic condition [23].

Jian et al. published a review about the role of progranulin in inflammation. They also mentioned the proinflammatory effect of progranulin in chronic inflammatory conditions such as obesity. They concluded with insights into the immunomodulating, anti-inflammatory, therapeutic potential of progranulin in treating diseases with an inflammatory aetiology [36]. In a review by Fasshauer et al., secretion of adipokines like progranulin were altered in adipose tissue dysfunction, and they may contribute to a spectrum of obesity-associated diseases. The authors also stated that adipokines are promising candidates both for novel pharmacological treatment strategies and as diagnostic tools [37].

There is evidence that the administration of progranulin in the mice hypothalamus significantly suppresses fasting-induced feeding and body weight gain in a dose-dependent manner. However, in obesity, a resistance to the anorexigenic effects of progranulin may contribute to increased food intake [33].

Our study harbours some limitations that must be mentioned. Firstly, the sample size is small, and the non-significant associations between progranulin and some factors could have become statistically significant if larger samples were studied. Secondly, 
our study is cross-sectional, and therefore causality of progranulin and other mediators such as IL- 6 cannot be established.

\section{Conclusions}

Our results suggest that elevated progranulin serum levels are associated with obesity. Because progranulin is a key adipokine that mediates obesity through pro-inflammatory adipokines, infertile and obese patients may benefit if their serum progranulin levels decrease. Further prospective investigations are merited to illuminate the role of progranulin on the pathogenesis of obesity.

\section{Acknowledgments}

This study was supported as a project (TIP19001.14.005) by the Department of Scientific Research Projects of Hitit University, Corum, Turkey.

\section{Compliance with ethical standards Conflict of interest}

The authors declare no conflicts of interest.

\section{Ethical approval}

This study was approved by the local Ethics Committee and the Institutional Review Board (reference number: E-15-563).

\section{Informed consent}

Written, informed consent was obtained from all volunteers.

\section{References}

1. Anakwe OO, Gerton GL. Acrosome biogenesis begins during meiosis: evidence from the synthesis and distribution of an acrosomal glycoprotein, acrogranin, during guinea pig spermatogenesis. Biol Reprod. 1990; 42(2): 317-328, indexed in Pubmed: 1692485

2. Daniel R, Daniels E, He Z, et al. Progranulin (acrogranin/PC cell-derived growth factor/granulin-epithelin precursor) is expressed in the placenta, epidermis, microvasculature, and brain during murine development. Dev Dyn. 2003; 227(4): 593-599, doi: 10.1002/dvdy.10341, indexed in Pubmed: 12889069.

3. Bateman A, Bennett HPJ. The granulin gene family: from cancer to dementia. Bioessays. 2009; 31(11): 1245-1254, doi: 10.1002/bies.200900086, indexed in Pubmed: 19795409.

4. Bateman A, Bennett HP. Granulins: the structure and function of an emerging family of growth factors. J Endocrinol. 1998; 158(2): 145-151, indexed in Pubmed: 9771457.

5. Koo DH, Park CY, Lee ES, et al. Progranulin as a prognostic biomarker for breast cancer recurrence in patients who had hormone receptor-positive tumors: a cohort study. PLoS One. 2012; 7(6): e39880, doi: 10.1371/journal. pone.0039880, indexed in Pubmed: 22761921.

6. Han JJ, Yu M, Houston N, et al. Progranulin is a potential prognostic biomarker in advanced epithelial ovarian cancers. Gynecol Oncol. 2011; 120(1): 5-10, doi: 10.1016/j.ygyno.2010.09.006, indexed in Pubmed: 20950846.

7. Lu Yi, Zheng L, Zhang W, et al. Growth factor progranulin contributes to cervical cancer cell proliferation and transformation in vivo and in vitro. Gynecol Oncol. 2014; 134(2): 364-371, doi: 10.1016/j.ygyno.2014.05.025, indexed in Pubmed: 24905774.
8. Demorrow S. Progranulin: a novel regulator of gastrointestinal cancer progression. Transl Gastrointest Cancer. 2013; 2(3): 145-151, doi: 10.3978/j. issn.2224-4778.2013.02.02, indexed in Pubmed: 24040621.

9. Donald CD, Laddu A, Chandham P, et al. Expression of progranulin and the epithelin/granulin precursor acrogranin correlates with neoplastic state in renal epithelium. Anticancer Res. 2001; 21(6A): 3739-3742, indexed in Pubmed: 11911241.

10. Finch N, Baker M, Crook R, et al. Plasma progranulin levels predict progranulin mutation status in frontotemporal dementia patients and asymptomatic family members. Brain. 2009; 132(Pt 3): 583-591, doi: 10.1093/brain/awn352, indexed in Pubmed: 19158106.

11. Tang W, Lu Yi, Tian QY, et al. The growth factor progranulin binds to TNF receptors and is therapeutic against inflammatory arthritis in mice. Science. 2011; 332(6028): 478-484, doi: 10.1126/science.1199214, indexed in Pubmed: 21393509.

12. Guerra RR, Kriazhev L, Hernandez-Blazquez FJ, et al. Progranulin is a stress-response factor in fibroblasts subjected to hypoxia and acidosis. Growth Factors. 2007; 25(4): 280-285, doi: 10.1080/08977190701781222, indexed in Pubmed: 18092235.

13. Zhu J, Nathan $C_{\text {, Jin }} \mathrm{W}$, et al. Conversion of proepithelin to epithelins: roles of SLPI and elastase in host defense and wound repair. Cell. 2002; 111(6): 867-878, indexed in Pubmed: 12526812.

14. Kessenbrock K, Fröhlich L, Sixt M, et al. Proteinase 3 and neutrophil elastase enhance inflammation in mice by inactivating antiinflammatory progranulin. J Clin Invest. 2008; 118(7): 2438-2447, doi: 10.1172/JCI34694, indexed in Pubmed: 18568075.

15. Eriksen JL, Mackenzie IRA. Progranulin: normal function and role in neurodegeneration. J Neurochem. 2008; 104(2): 287-297, doi: 10.1111/j. 1471-4159.2007.04968.x, indexed in Pubmed: 17953663.

16. Gundogan K, Bayram F, Gedik V, et al. Metabolic syndrome prevalence according to ATP III and IDF criteria and related factors in Turkish adults. Arch Med Sci. 2013; 9(2): 243-253, doi: 10.5114/aoms.2013.34560 indexed in Pubmed: 23671434.

17. Satman I, Omer B, Tutuncu Y, et al. TURDEP-II Study Group Twelve-year trends in the prevalence and risk factors of diabetes and prediabetes in Turkish adults. Eur J Epidemiol. 2013; 28(2): 169-180, doi: 10.1007/s10654-013-9771-5, indexed in Pubmed: 23407904.

18. Obesity: preventing and managing the global epidemic. World Health Organization, Geneva 2000

19. Marshall NE, Spong CY. Obesity, pregnancy complications, and birth outcomes. Semin Reprod Med. 2012; 30(6): 465-471, doi 10.1055/s-0032-1328874, indexed in Pubmed: 23074004.

20. Inal HA, Yilmaz N, Gorkem U, et al. The impact of follicular fluid adiponectin and ghrelin levels based on BMI on IVF outcomes in PCOS. Endocrinol Invest. 2016; 39(4): 431-437, doi: 10.1007/s40618-015-0392-6, indexed in Pubmed: 26410834

21. Rittenberg V, Seshadri S, Sunkara SK, et al. Effect of body mass index on IVF treatment outcome: an updated systematic review and meta-analysis. Reprod Biomed Online. 2011; 23(4): 421-439, doi: 10.1016/j rbmo.2011.06.018, indexed in Pubmed: 21885344

22. Yoo H, Hwang S, Hong $\mathrm{H}$, et al. Implication of Progranulin and C1q/TNF-Related Protein-3 (CTRP3) on Inflammation and Atherosclerosis in Subjects with or without Metabolic Syndrome. PLoS ONE. 2013, 8(2): e55744, doi: 10.1371/journal.pone.0055744.

23. Matsubara T, Mita A, Minami K, et al. PGRN is a key adipokine mediating high fat diet-induced insulin resistance and obesity through IL-6 in adipose tissue. Cell Metab. 2012; 15(1):38-50, doi: 10.1016/j.cmet.2011.12.002, indexed in Pubmed: 22225875.

24. Qu H, Deng H, Hu Z. Plasma Progranulin Concentrations Are Increased in Patients with Type 2 Diabetes and Obesity and Correlated with Insulin Resistance. Mediators of Inflammation. 2013; 2013: 1-6, doi 10.1155/2013/360190.

25. Yoo $\mathrm{H}, \mathrm{Hwang} \mathrm{S}$, Hong $\mathrm{H}$, et al. Implication of Progranulin and C1q/TNF-Related Protein-3 (CTRP3) on Inflammation and Atherosclerosis in Subjects with or without Metabolic Syndrome. PLoS ONE. 2013; 8(2): e55744, doi: 10.1371/journal.pone.0055744.

26. Klöting N, Fasshauer M, Dietrich A, et al. Insulin-sensitive obesity. Am Physiol Endocrinol Metab. 2010; 299(3): E506-E515, doi: 10.1152/ajpendo.00586.2009, indexed in Pubmed: 20570822

27. Nicoletto B, Canani L. The role of progranulin in diabetes and kidney disease. Diabetology \& Metabolic Syndrome. 2015; 7(1): 117, doi 10.1186/s13098-015-0112-6

28. $\mathrm{Li} \mathrm{H}, \mathrm{Zhou} \mathrm{Bo,} \mathrm{Xu} \mathrm{L}$, et al. Circulating PGRN is significantly associated with systemic insulin sensitivity and autophagic activity in metabolic syndrome. Endocrinology. 2014; 155(9): 3493-3507, doi: 10.1210/en.2014-1058, indexed in Pubmed: 24971611.

29. Waki H, Tontonoz P. Endocrine Functions of Adipose Tissue. Annual Review of Pathology: Mechanisms of Disease. 2007; 2(1): 31-56, doi 10.1146/annurev.pathol.2.010506.091859.

30. Nguyen AD, Nguyen TA, Martens LH, et al. Progranulin: at the interface of neurodegenerative and metabolic diseases. Trends Endocrinol 
Metab. 2013; 24(12): 597-606, doi: 10.1016/j.tem.2013.08.003, indexed in Pubmed: 24035620.

31. Cao Y. Angiogenesis modulates adipogenesis and obesity. J Clin Invest. 2007; 117(9): 2362-2368, doi: 10.1172/JCI32239, indexed in Pubmed: 17786229.

32. Toh H, Cao M, Daniels E, et al. Expression of the growth factor progranulin in endothelial cells influences growth and development of blood vessels: a novel mouse model. PLoS One. 2013; 8(5): e64989, doi: 10.1371/journal.pone.0064989, indexed in Pubmed: 23741441.

33. Kim HK, Shin MS, Youn BS, et al. Involvement of progranulin in hypothalamic glucose sensing and feeding regulation. Endocrinology. 2011; 152(12): 4672-4682, doi: 10.1210/en.2011-1221, indexed in Pubmed: 21933869
34. Egashira Y, Suzuki Y, Azuma Y, et al. The growth factor progranulin attenuates neuronal injury induced by cerebral ischemia-reperfusion through the suppression of neutrophil recruitment. J Neuroinflammation. 2013; 10: 105, doi: 10.1186/1742-2094-10-105, indexed in Pubmed: 23972823.

35. Kanazawa M, Kawamura K, Takahashi T, et al. Multiple therapeutic effects of progranulin on experimental acute ischaemic stroke. Brain. 2015; 138(7): 1932-1948, doi: 10.1093/brain/awv079.

36. Jian J, Konopka J, Liu C. Insights into the role of progranulin in immunity, infection, and inflammation. J Leukoc Biol. 2013; 93(2): 199-208, doi: 10.1189/jlb.0812429, indexed in Pubmed: 23089745.

37. Fasshauer M, Blüher M. Adipokines in health and disease. Trends Pharmacol Sci. 2015; 36(7): 461-470, doi: 10.1016/j.tips.2015.04.014, indexed in Pubmed: 26022934 